

\title{
EFFECTS OF WORKING CAPITAL CYCLE ON PROFITABILITY OF MANUFACTURING FIRMS IN GHANA
}

\author{
1* Alfonse Kisilu, \\ 1* Post Graduate Student, the School Of Management and Commerce \\ STRATHMORE UNIVERSITY
}

*Corresponding Author's Email: alfornse@gmail.com

\begin{abstract}
Purpose: The study was on the effects of working capital cycle on profitability of manufacturing firms in Ghana.

Methodology: The research design used in this study was explanatory research design. There are 78 large manufacturing firms in Loan Book of Barclays Bank Ghana. The population of the study is therefore 78 firms. The sampling frame was the loan book of Barclays Bank Ghana. It is for this reason that the study considered $50 \%$ of the population to be the sample size. This yielded 39 large manufacturing firms. The study used secondary data only for the purposes of analysis and drawing of conclusions. Descriptive statistics included mean scores and inferential statistics included regression modeling.

Results: Results show that there is a negative relationship between profit before tax and mean debtor's collection period whose beta coefficients is -1817.81 . Results show that there is a negative relationship between profit before tax and mean inventory conversion period whose beta coefficients is -103.762 . The mean payable deferral period had a positive relationship with profitability with a beta coefficient of 1097.073. The findings show that there is a negative relationship between profit before tax and working capital conversion cycle with a beta coefficient of -816.198 .

Policy recommendation: It was recommended that speeding up payments to suppliers might increase profitability because firms often receive a substantial discount for prompt payment.It was also recommended that the government should intervene by way of a legislation that would impose penalty interest for delayed payment of commercial debts. Such a provision would create a level playing field by binding all firms to pay promptly and ease the cash flow problems of small firms, who will be compensated for any overdue payments. It was recommended that the owners of firms be made more aware and trained on the best credit management practice. That way, they could reduce the amount of overdue debt and alleviate the problem.
\end{abstract}

Keywords: inventory conversion, receivables conversion period, payable deferral period, working capital cycle 


\subsection{INTRODUCTION}

\subsection{Background of the study.}

Cash flows in a cycle into, around and out of a business. It is the business's life blood and every manager's primary task is to help keep it flowing and to use the cash flow to generate profits. If a business is operating profitably, then it should, in theory, generate cash surpluses. If it doesn't generate surpluses, the business will eventually run out of cash and expire (Pass and Pike 1984).

The faster a business expands the more cash it will need for working capital and investment. The cheapest and best sources of cash exist as working capital right within business. Good management of working capital will generate cash, will help improve profits and reduce risks. Bear in mind that the cost of providing credit to customers and holding stocks can represent a substantial proportion of a firm's total profits (Deloof, 2003).

Working capital is defined as a firm's investment in short term assets such as cash, marketable securities, inventory and accounts receivable, (Besley, Eugene. \& Brigham, 2006). Typically a firm purchases raw materials, converts them to finished products, and sells them for cash or credit and thereby collect sales made on credit. The length of time between when a company makes payment for raw materials and time when it's paid for its sales is referred to as the cash conversion cycle. Cash Conversion cycle is a key measure of a firm's working capital management (Deloof, 2003). In managing working capital cycle, firms face a trade off between holding more current assets to avoid the danger of running out of trading assets and the cost of holding current assets. To minimise this trade off firms need to establish the sufficient levels of current assets based on their experience with respect to supply of raw materials and the size of the market for their products. This period is expected to vary from market to market depending on how dependable the supply chain is and the nature of customers among other factors (Sharma and Kumar, 2011).

A longer cash conversion cycle can increase sales by selling more on credit while always holding sufficient stocks; hence one can argue that this will lead to increased profitability. In the event that a firm pursues an aggressive working capital management by holding low levels of inventory at any one point in time, the firm risks losing increase in sales because of the time required to restock should demand increase unexpectedly. A reduction in credit terms could also lead to loss of sales from customers who expect longer credit sales. Maintaining high stock levels reduces the risk of interruptions and loss of business due to scarcity of product and can protect against supply interruptions (Peel, Wilson \& Howorth, 2000).

On the other hand profitability might reduce with a longer conversion cycle if the costs related to a longer conversion cycle are higher than the benefits of giving longer credit terms to customers. Holding high current assets, that is, raw materials, stocks and debtors requires significant storage facilities especially for manufacturing concerns with associated risks such as products become obsolete (if perishable), theft and requirements by International Accounting Standards to raise provision of some of the assets (Besley, Eugene \& Brigham, 2006).

\subsection{Statement of the Problem}

To be effective, working capital management requires a clear specification of the objectives to be achieved. The two main objectives of working capital management are to increase the 
profitability of a company and to ensure that it has sufficient liquidity to meet short-term obligations as they fall due and so continue in business (Pass and Pike, 1984). Profitability is related to the goal of shareholder wealth maximization, so investment in current assets should be made only if an acceptable return is obtained. While liquidity is needed for a company to continue in business, a company may choose to hold more cash than is needed for operational or transaction needs, for example for precautionary or speculative reasons. The twin goals of profitability and liquidity will often conflict since liquid assets give the lowest returns. Cash kept in a safe will not generate a return, for example, while a six-month bank deposit will earn interest in exchange for loss of access for the six-month period (Garcia-Teruel and Martinez-Solano, 2007).

Because working capital management is so important, a company will need to formulate clear policies concerning the various components of working capital. Key policy areas relate to the level of investment in working capital for a given level of operations and the extent to which working capital is financed from short-term funds such as a bank overdraft. A company should have working capital policies on the management of inventory, trade receivables, cash and shortterm investments in order to minimize the possibility of managers making decisions which are not in the best interests of the company (Vishnani and Shah, 2007; Garcia-Teruel and MartinezSolano,2007; Mathuva,2009)

Finally, there is a direct relationship between sales growth and current asset levels. For example, higher sales volume may be achieved only if production increases. Higher production, however, requires greater investment in inventories. Additionally, if a firm buys on credit, its accounts payable increase and when it sells on credit, its accounts receivable increase. Therefore, higher sales require a larger investment in current assets which, in turn, requires greater financing. Profits result from selling the product or the service. If the goal of the business is higher profits, the importance of effective working capital management becomes obvious (Vishnani and Shah, 2007; Garcia-Teruel and Martinez-Solano, 2007).

Studies such as Vishnani and Shah,2007; Garcia-Teruel and Martinez-Solano,2007; Deloof, 2003; Sharma and Kumar, 2011; Van Horne, and Wachowicz, 2009; Lindsay ,2008 were done in developed and emerging economies. Studies in developing countries such as Ghana are scanty. The paucity of the studies in Ghana indicates that there is an imminent research gap. In addition, most studies for instance, Vishnani and Shah, 2007; Garcia-Teruel and Martinez-Solano,2007; Deloof, 2003; Sharma and Kumar, 2011 tend to concentrate on aspect of the working capital cycle. The studies either concentrate on receivable collection period or on inventory collection period. Hence, a conceptual gap exists since this study will attempt to address all the components of the working capital cycle. Another research gaps stems from the lack of conclusiveness of the studies. While some studies report positive and significant relationship between working cycle components and profitability, others report a negative relationship while other reports no relationship at all. This study will therefore seek to offer an understanding of how the relationship between working capital cycle components and profitability of corporate businesses in Ghana plays out. This study seeks to provide evidence to bridge that gap by exploring the effects of working capital management cycle for manufacturing concerns domiciled in Ghana and banking with Barclays Bank Ghana. 
The study is not aware of the existence of a study that addressed the effects of working capital cycle on profitability in the manufacturing sector in Ghana. It is for this reason that this study attempts to assess the effects of working capital cycle in manufacturing sector.

\subsection{Research objectives}

- To assess the effect of inventory conversion period on profitability of large manufacturing firms in Ghana.

- To determine the effect of the receivables conversion period on profitability of large manufacturing firms in Ghana.

- To establish effect of payable deferral period on profitability of large manufacturing firms in Ghana.

- To establish the overall effect of the working capital cycle conversion period on profitability of large manufacturing firms in Ghana.

\subsection{LITERATURE REVIEW}

\subsection{Empirical Review}

\subsubsection{Effect of inventory conversion period on profitability}

The inventory conversion period is the average time taken to use up raw materials, plus the average time taken to convert raw materials into finished goods, plus the average time taken to sell finished goods to customers. The inventory conversion period might be several months for an engineering or manufacturing company, but negligible for a service company. The inventory conversion period can be reduced by shortening the length of the production cycle, for example by more effective production planning or by outsourcing part of the production process. The amount of inventory within the production process can be reduced by using just-in-time (JIT) production methods or by employing production methods which are responsive to changing sales (Garcia-Teruel and Martinez-Solano, 2007)

\subsubsection{Effect of the receivables conversion period on firm profitability.}

Receivable conversion period (RCP) is the time between the sale of the final product on credit and cash receipts for the accounts receivable. The trade receivables period is the average time taken by credit customers to settle their accounts (Van Horne, and Wachowicz, 2009).

Although trade credit has long been an important source of finance for business firms it is one of the least understood methods of doing business. One possible reason for the misconceptions about trade credit is its varied nature. It is not only financial in nature but also reflects production and marketing decisions (Long, Malitz \& Ravid, 1993). Numerous theories had been posited in the last three decades in attempt to explain its existence and use. Credit management has been a neglected function in many organisations with the only focus given to the end activity of debt collection. The front end activities of credit management such as negotiations, risk screening, using credit information and establishing credit policies has been neglected (Peel, Wilson \& 
Howorth, 2000). This had led to failure of more and more businesses even when some were having a positive trend in growth of sales.

\subsubsection{Effect of payable deferral period on firm profitability}

The trade payables deferral period is the average time taken by a company to pay its trade payables, i.e. its suppliers, (Van Horne, and Wachowic,2009). Payable deferral period (PDP) is the time between purchase of raw material on credit and cash payments for the resulting accounts payable (Maysami 2009).

\subsubsection{The overall effect of the working capital cycle conversion period on firm profitability.}

The effects of working capital management upon corporate performance have been the focus of a substantial amount of theoretical and empirical research for many years and in different environments. Traditional approach to the interaction between cash conversion cycle and profitability posits that relatively long cash conversion periods tend to decrease profitability (Samiloglu and Demirgunes, 2008). It means that reducing working capital investment would positively influence the companies' profitability by reducing the proportion of current assets in total assets. Most studies in this area show that companies can improve their profitability by shortening the cash conversion cycle because they found a strong negative relationship between these two variables. Various results were obtained when it comes to the relationship between different components of the Cash Conversion Cycle and corporate profitability. 


\subsection{Conceptual Framework}

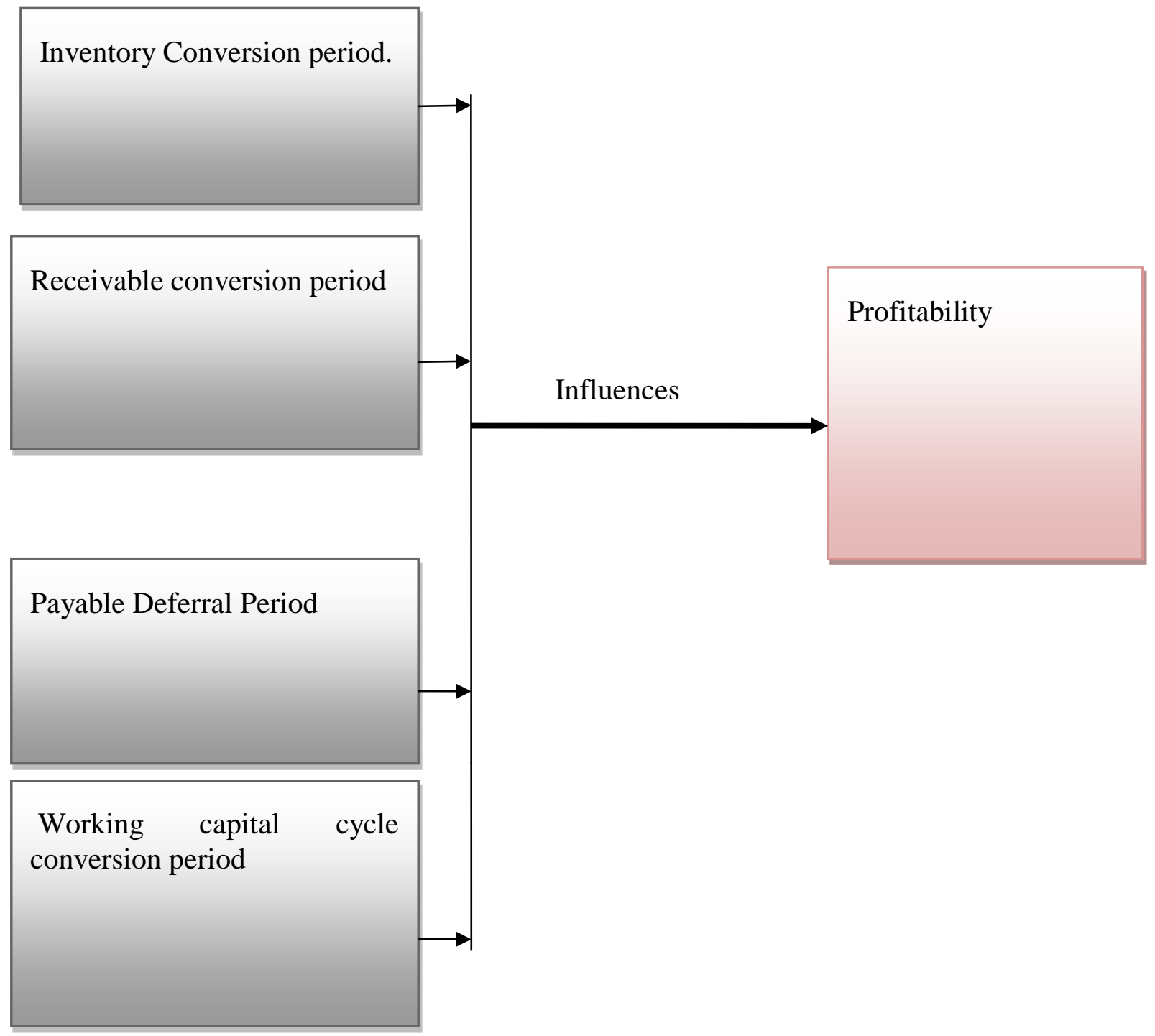

Independent variables

Dependent Variable

Source: Figure 1: Conceptual Model Researcher (2013)

\subsection{METHODOLOGY}

The research design used in this study was explanatory research design. There are 78 large manufacturing firms in Loan Book of Barclays Bank Ghana. The population of the study is 
therefore 78 firms. The sampling frame was the loan book of Barclays Bank Ghana. It is for this reason that the study considered $50 \%$ of the population to be the sample size. This yielded 39 large manufacturing firms. The study used secondary data only for the purposes of analysis and drawing of conclusions. Descriptive statistics included mean scores and inferential statistics included regression modeling.

\subsection{RESULTS FINDINGS}

\section{1 descriptive results}

\subsubsection{Descriptive Results for Working Capital Cycle}

Results in Table 4.1 revealed that the average profit before tax (PBT) for the 39 manufacturing firms was 43,978.3 Ghanaian cedi. The minimum reported profit before tax was 3406.6 Ghanaian cedi while the maximum was 170,938 . The profit before tax was spread within a standard deviation of 43,739.4 and this implies that there was a wide spread of reported profitability from the mean profitability. This may further be explained by sectoral difference in profitability.

Study results show that the average annual debtor's collection period was 31.1. The minimum annual debtor's collection period was 6.4, while the maximum was 48.6. The mean of the annual debt collection period was spread within a standard deviation of 12.9. This implies that there was a wide spread of the reported annual average debtor's collection period from the mean collection period.

The findings also imply that the mean of annual inventory conversion period was 38.5.The minimum annual debtor's conversion period was 6.4 , while the maximum was 83.8. The mean of the annual debt conversion period was spread within a standard deviation of 17.8. This implies that there was a wide spread of the reported annual average debtor's conversion period from the mean collection period.

The results presented in Table 4.1 revealed that the mean annual deferral period for the 39 manufacturing firms was 46.5. The minimum reported deferral period was 16.8 while the maximum was 114.8. The deferral period was spread within a standard deviation of 22.4 and this implies that there was a wide spread of reported deferral period from the mean deferral period.

Table 1 Descriptive Results

\begin{tabular}{|l|r|r|r|r|l|}
\hline & $\mathrm{N}$ & \multicolumn{1}{|c|}{ Minimum } & Maximum & Mean & $\begin{array}{l}\text { Std. } \\
\text { Deviation }\end{array}$ \\
\hline Mean PBT & & & & & \\
\end{tabular}


International Journal of Finance And Accounting ISSNxxxx-xxxx (Paper) ISSN 2518-4113 (Online)

Vol.1, Issue No.3, pp 95 - 117, 2017

\begin{tabular}{l|l|}
\hline 31.1 & 12.9 \\
\hline 38.5 & 17.8 \\
\hline 46.5 & 22.4 \\
\hline
\end{tabular}

\begin{tabular}{|l|c|r|r|r|l|} 
Mean debtors collection period & 39 & 6.4 & 48.6 & 31.1 & 12.9 \\
\hline Mean inventory conversion period & 39 & 6.4 & 83.8 & 38.5 & 17.8 \\
\hline Mean payable deferral period & 39 & 16.8 & 114.8 & 46.5 & 22.4 \\
\hline
\end{tabular}

\subsubsection{Trend Results for Working Capital Cycle Period}

Trend results in Figure 4.1 revealed that there was a consistent rise in profit before tax across the five years of study. The average profit in year 2009 was 32049.56 Ghanaian cedi. It rose to 39,569.28 Ghanaian cedi in year 2010 but declined slightly to 38,855.05 Ghanaian cedi in year2011. It then rose to 44,383.74 Ghanaian cedi in year 2012 and to $65,033.85$ Ghanaian cedi in year 2012. The linear plot yielded an $\mathrm{r}$ square of 0.793 implying that $79.3 \%$ of changes in profitability can be explained by time and this further revealed a consistent trend.

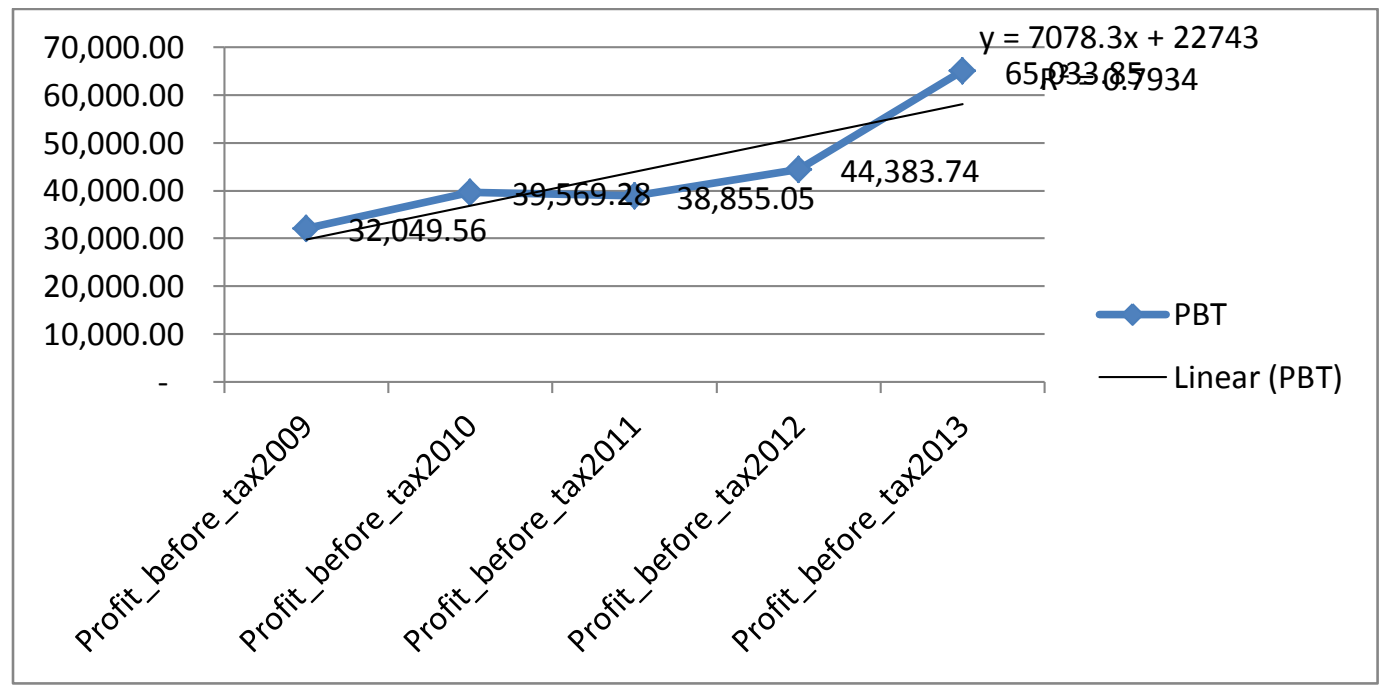

\section{Figure 2 : Profit before Tax}

Trend results in Figure 4.2 revealed that there was a consistent decline in the annual debtor's collection period across the five years of study. The debtor's collection period in year 2009 was 39.08. It dropped to 33.59 in year 2010 and further to 30.95 in the year 2011. The debtor's collection period dropped to 28.67 in 2012 and further to 23.18 in year 2013. The linear plot yielded an $r$ square of 0.973 implying that $97.3 \%$ of changes in debtor's collection period can be explained by time and this further revealed a consistent trend. 


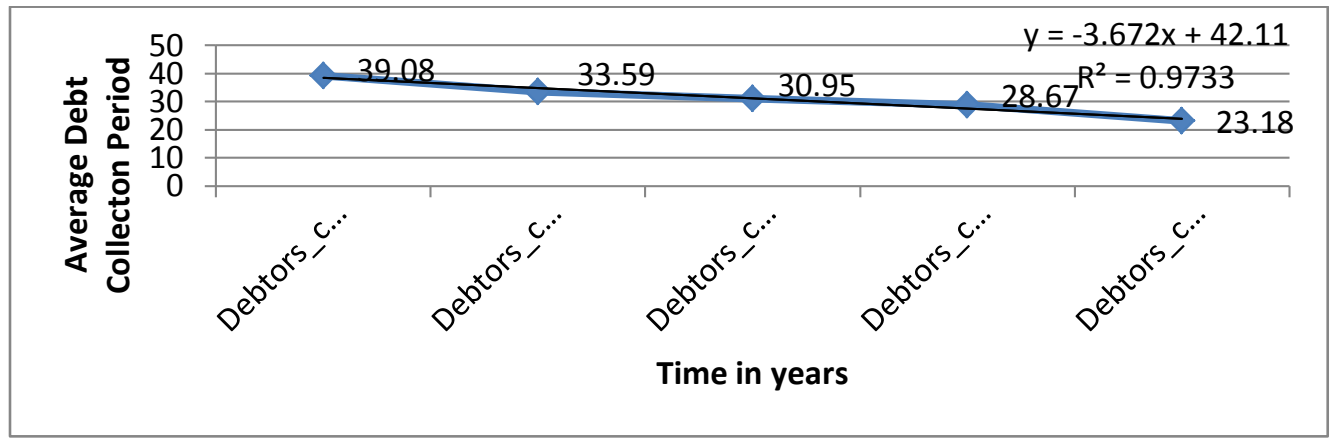

\section{Figure 3: Debtor's collection period}

Trend results in Figure 4.3 revealed that there was a consistent decline in debtor's inventory conversion period across the five years of study. The debtor's inventory conversion period in year 2009 was 42.18 . It dropped to 38.41 in year 2010 and further declined to 39.28 in year 2011. It then dropped to 38.46 in year 2012 and dropped further to 33.92 in the year 2013. The linear plot yielded an $\mathrm{r}$ square of 0.772 implying that $77.2 \%$ of changes in debtor's inventory conversion period can be explained by time and this further revealed a consistent trend.

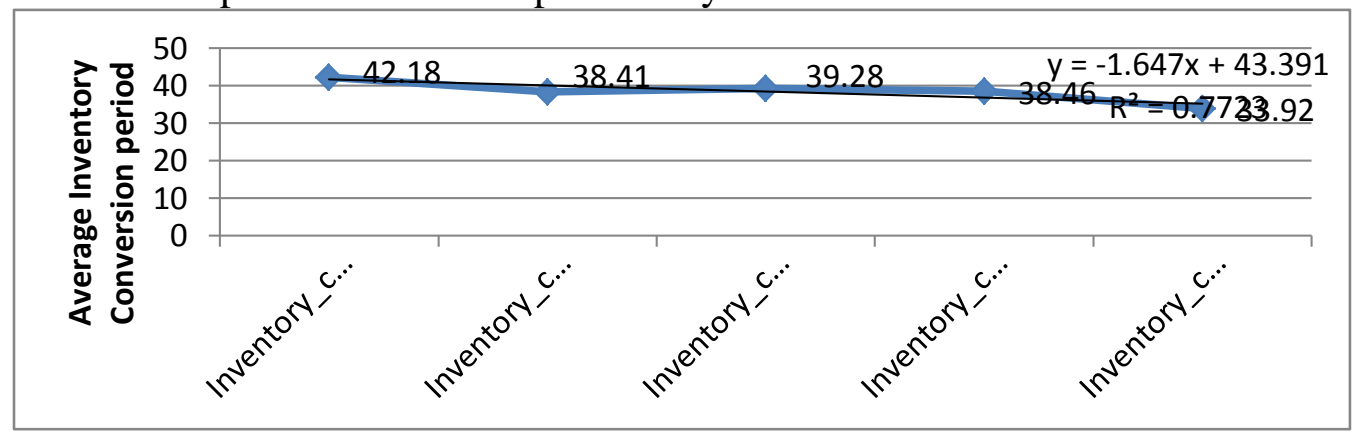

\section{Figure 4: Debtor's Inventory Conversion Period}

Trend results in Figure 4.4 revealed that there was a consistent rise in payable deferral period across the five years of study. The average payable deferral period in year 2009 was 42.13. It slightly dropped to 40.77 in year 2010 but rose to 47.92 in year 2011. It then rose to 50.54 in year 2012 and to 51.38 in year 2013. The linear plot yielded an $r$ square of 0.849 implying that $84.9 \%$ of changes in payable deferral period can be explained by time and this further revealed a consistent trend. 


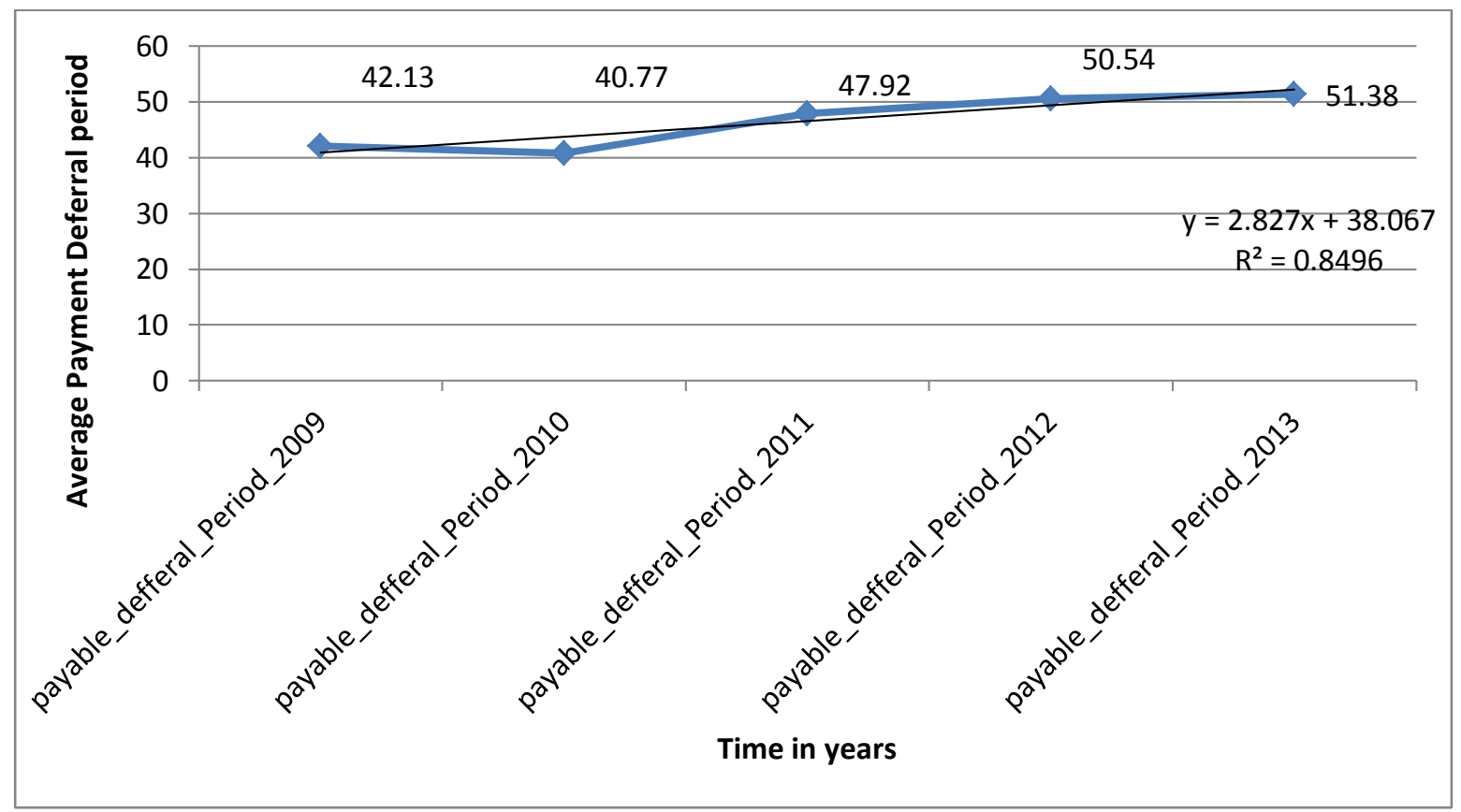

\section{Figure 5: Payable Deferral Period}

\subsubsection{Sectoral Analysis of Working Capital Cycle Period}

Sectoral results were conducted in order to establish which sectors had the minimum and maximum values. Figure 4.5 revealed that building, construction and mining sector had the highest average profit before tax (162,561 Ghanaian cedi) while timber, wood and furniture sector had the lowest average profit before tax of 4, 324 Ghanaian cedi.

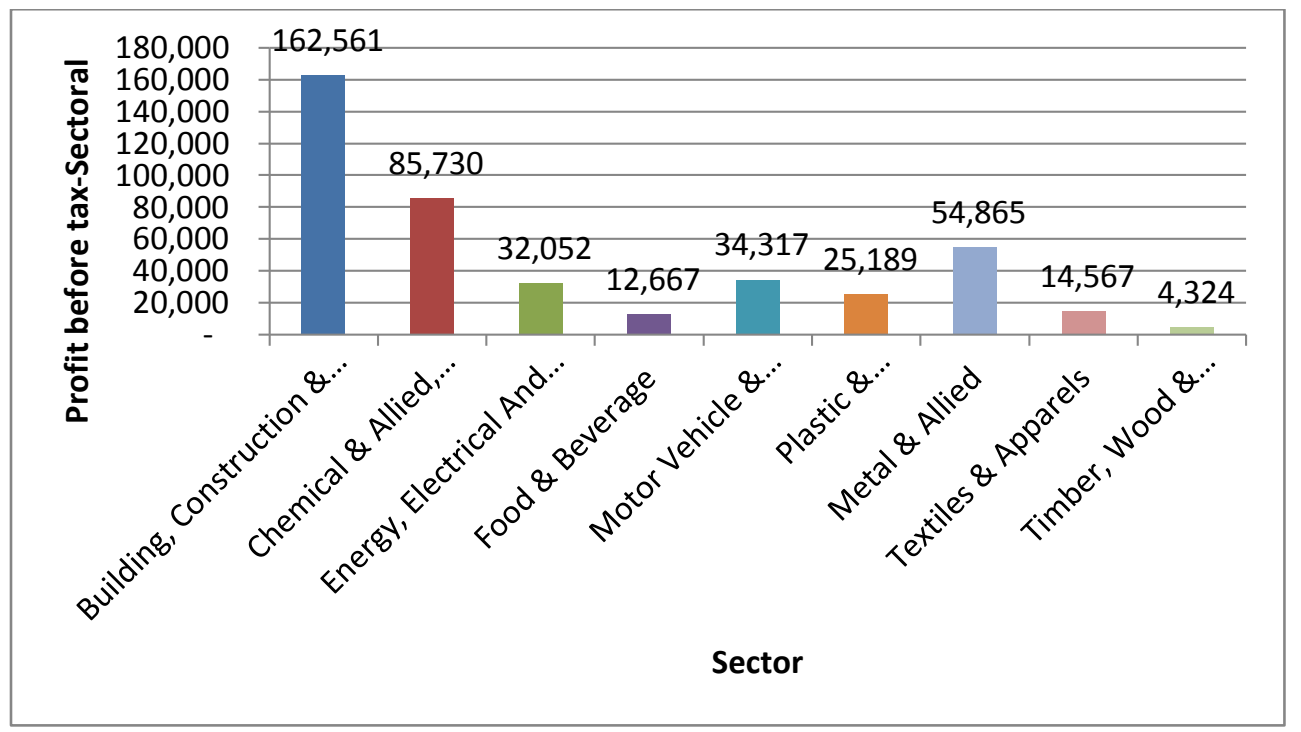




\section{Figure 6 : Profit Sectoral Analysis}

Sectoral results were conducted in order to establish which sectors had the minimum and maximum values on average debt collection period. Figure 4.6 revealed that motor vehicles and accessories had the highest average debt collection period (48) while building, construction and mining sector had the lowest average debt collection period (19).

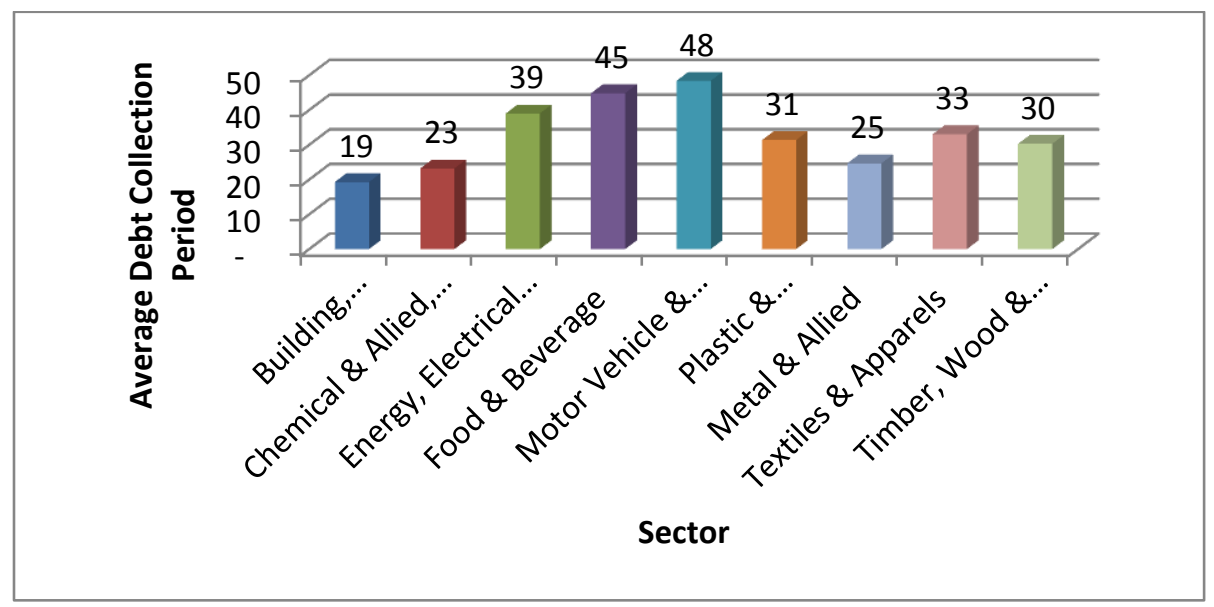

\section{Figure 7: Average Debtor's Collection Period Sectorial Analysis}

Sectoral results were conducted in order to establish which sectors had the minimum and maximum values on average inventory conversion period. Figure 4.7 revealed that motor vehicles and accessories had the highest average inventory conversion period (68) while building, construction and mining sector had the lowest average inventory conversion period (10).

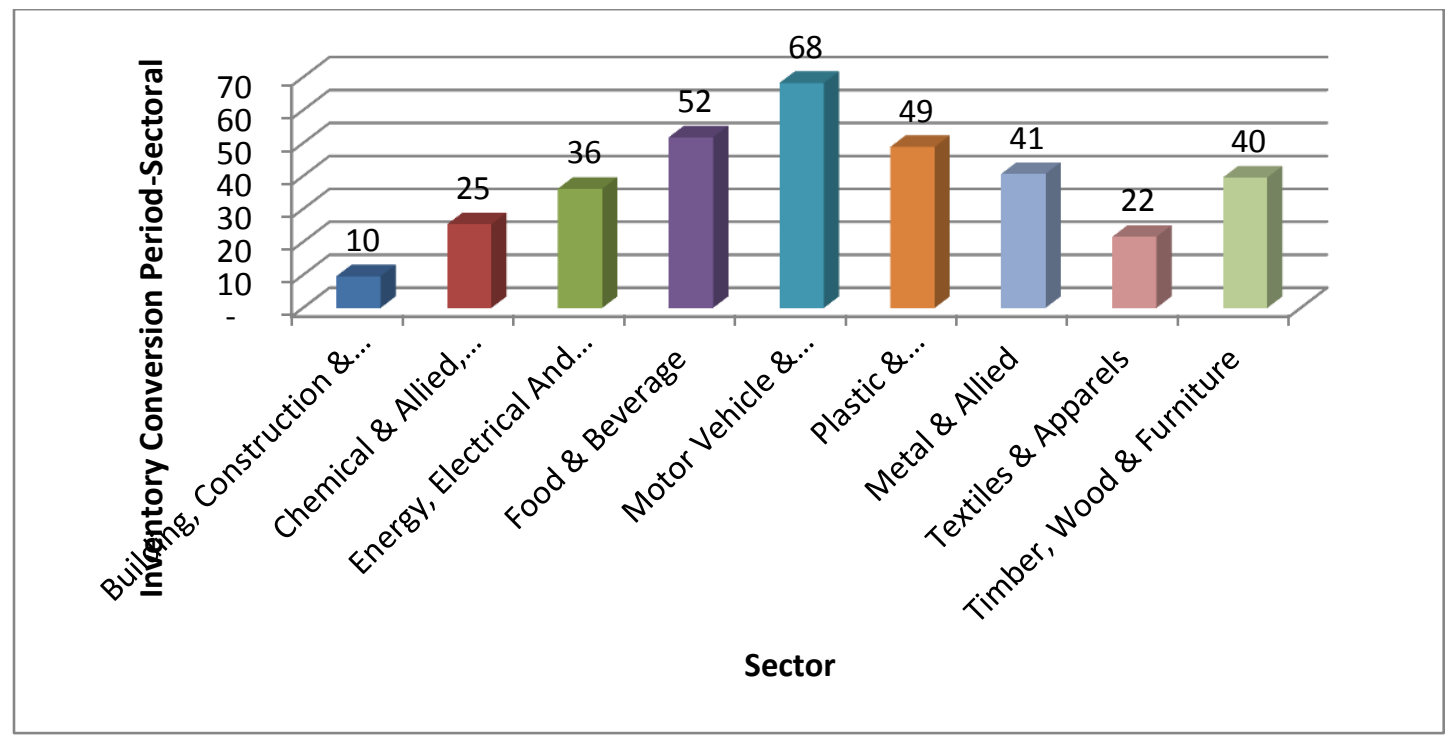




\section{Figure 8: Inventory Conversion Period Sectoral Analysis}

Sectoral results were conducted in order to establish which sectors had the minimum and maximum values on average payment deferral period. Figure 4.8 revealed that the building, construction and mining sector had the highest average payment deferral period (85) while the motor vehicles and accessories had the lowest average payment deferral period (25).

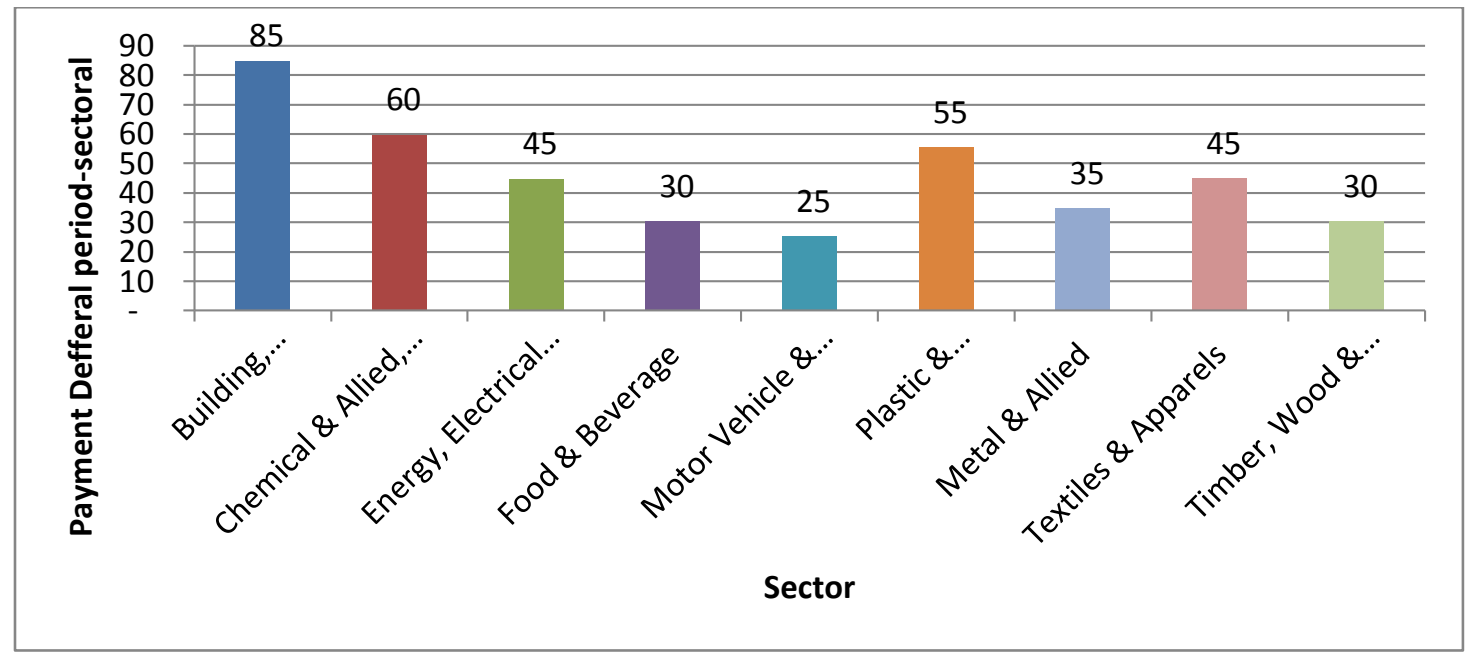

Figure 9: Average Payment Deferral Sectoral Analysis

\subsection{Correlation Results}

Pearson's correlation indicates the relationship between two variables. It ranges from 1 to -1 where 1 indicates a strong positive correlation and a -1 indicates a strong negative correlation and a zero indicates lack of relationship between the two variables. The closer the correlation tends to zero the weaker it becomes. The correlation between average profit before tax and the mean debtor's collection period was strong and negative (-0.493) but statistically significant (0.001). The correlation between average profit before tax and the mean inventory conversion period was weak and negative (-0.404) but was statistically significant $(0.011)$.The correlation between average profit before tax and mean payable deferral period was strong and positive $(0.523)$ and was statistically significant $(0.001)$. 
International Journal of Finance And Accounting

ISSNxxxx-xxxx (Paper) ISSN 2518-4113 (Online)

Vol.1, Issue No.3, pp 95 - 117, 2017

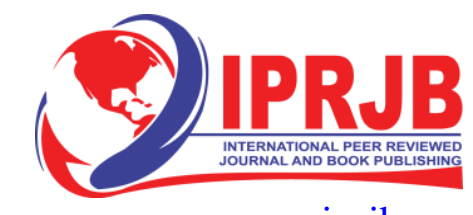

\section{Table 2: Pearson's Correlation}

\begin{tabular}{|c|c|c|c|c|c|}
\hline & & Mean pbt & $\begin{array}{l}\text { Mean debtors } \\
\text { collection period }\end{array}$ & $\begin{array}{l}\text { Mean } \\
\text { inventory } \\
\text { conversion } \\
\text { period }\end{array}$ & $\begin{array}{l}\text { Mean payable } \\
\text { deferral period }\end{array}$ \\
\hline \multirow[t]{3}{*}{ Mean PBT } & $\begin{array}{l}\text { Pearson } \\
\text { Correlation }\end{array}$ & 1 & & & \\
\hline & $\begin{array}{l}\text { Sig. }(2- \\
\text { tailed) }\end{array}$ & & & & \\
\hline & $\mathrm{N}$ & 39 & & & \\
\hline \multirow[t]{3}{*}{$\begin{array}{l}\text { Mean debtors } \\
\text { collection period }\end{array}$} & $\begin{array}{l}\text { Pearson } \\
\text { Correlation }\end{array}$ & $-.493 * *$ & 1 & & \\
\hline & $\begin{array}{l}\text { Sig. (2- } \\
\text { tailed) }\end{array}$ & 0.001 & & & \\
\hline & $\mathrm{N}$ & 39 & 39 & & \\
\hline \multirow[t]{3}{*}{$\begin{array}{l}\text { Mean inventory } \\
\text { conversion period }\end{array}$} & $\begin{array}{l}\text { Pearson } \\
\text { Correlation }\end{array}$ & $-.404 *$ & 0.292 & 1 & \\
\hline & $\begin{array}{l}\text { Sig. }(2- \\
\text { tailed) }\end{array}$ & 0.011 & 0.071 & & \\
\hline & $\mathrm{N}$ & 39 & 39 & 39 & \\
\hline \multirow[t]{3}{*}{$\begin{array}{l}\text { Mean payable } \\
\text { deferral period }\end{array}$} & $\begin{array}{l}\text { Pearson } \\
\text { Correlation }\end{array}$ & $.523 * *$ & 0.1 & $-.365^{*}$ & 1 \\
\hline & $\begin{array}{l}\text { Sig. (2- } \\
\text { tailed) }\end{array}$ & 0.001 & 0.547 & 0.022 & \\
\hline & $\mathrm{N}$ & 39 & 39 & 39 & 39 \\
\hline
\end{tabular}

\subsection{Regression Results}

\section{Model 1:}

Table 3 below shows the fitness of the regression model in explaining the variables under study. The results indicate that the variables; mean payable deferral period, mean debtors collection period and mean inventory conversion period were satisfactorily explaining the mean profit before tax. This conclusion is supported by the $\mathrm{R}$ square of 0.575 . This further means that the independent variables can explain $57.5 \%$ of the dependent variable (profit before tax). 
International Journal of Finance And Accounting ISSNxxxx-xxxx (Paper) ISSN 2518-4113 (Online)

Vol.1, Issue No.3, pp 95 - 117, 2017

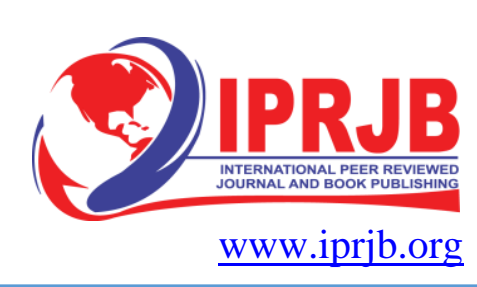

\begin{tabular}{|l|r|l|r|r|r|}
\hline & Coefficients & & Coefficients & & \\
\hline & B & \multicolumn{1}{l|}{$\begin{array}{l}\text { Std. } \\
\text { Error }\end{array}$} & Beta & & \\
\hline (Constant) & 53431.81 & 19592.84 & & 2.727 & 0.010 \\
\hline $\begin{array}{l}\text { Mean debtors collection } \\
\text { period }\end{array}$ & -1817.81 & 401.737 & -0.536 & -4.525 & 0.000 \\
\hline $\begin{array}{l}\text { Mean inventory conversion } \\
\text { period }\end{array}$ & -103.762 & 310.532 & -0.042 & -0.334 & 0.740 \\
\hline Mean payable deferral period & 1097.073 & 238.273 & 0.561 & 4.604 & 0.000 \\
\hline $\begin{array}{l}\text { a Dependent Variable: mean } \\
\text { pbt }\end{array}$ & & & & & \\
\hline
\end{tabular}

Profitability $=$ 53431.81-1817.81 Debtor collection period-103.762 Inventory conversion period+1097.073 Payable Deferral period

\section{Model 2:}

Table 6 below shows the fitness of the regression model in explaining the variables under study. The results indicate that working capital and conversion cycle was satisfactorily explaining the mean profit before tax. This conclusion is supported by the $\mathrm{R}$ square of 0.471 . This further means that the independent variable can explain $47.1 \%$ of the independent variable (profit before tax).

\section{Table 6 Model Fitness}

\begin{tabular}{|l|r|c|c|c|}
\hline \multicolumn{5}{|c|}{ Model Summary } \\
\hline Model & $\mathrm{R}$ & R Square & Adjusted R Square & $\begin{array}{c}\text { Std. Error of the } \\
\text { Estimate }\end{array}$ \\
\hline 1 & \multicolumn{1}{|c|}{$.686^{\mathrm{a}}$} & .471 & .457 & 32231.6760 \\
\hline \multicolumn{2}{|r|}{ a. Predictors: (Constant), Working capital Conversion cycle } \\
\hline
\end{tabular}

ANOVA statistics presented on Table 4.7 indicate that the overall model was statistically significant. This was supported by a probability (p) value of 0.000 . The reported $p$ value was less than the conventional probability of 0.05 significance levels thus its significance in the study. These results indicate that the working capital conversion cycle was a good predictor of profit before tax.

Table 7 Analysis of Variance

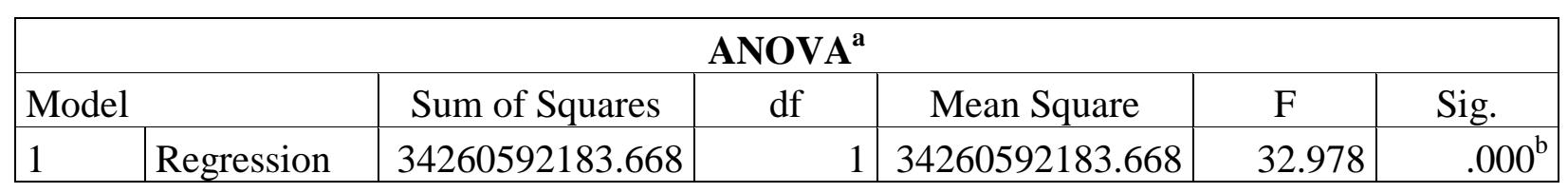




\begin{tabular}{|l|l|l|l|l|l|l|}
\hline & Residual & 38438594687.911 & 37 & 1038880937.511 & & \\
\hline & Total & 72699186871.579 & 38 & & & \\
\hline
\end{tabular}

a. Dependent Variable: mean pbt

b. Predictors: (Constant), Working capital conversion cycle

Regression of coefficients results in Table 8 shows that there is a negative relationship between profit before tax and working capital conversion cycle with a beta coefficient of -816.198 . However, the working capital conversion cycle was a statistically significant variable in the study with a significance level of 0.000 which is lower than the probability conventional of 0.05 . This means that an increase in one unit of working capital conversion cycle leads to a subsequent decrease of the dependent variable (profit before tax) by -816.198 units.

Table 8 Regression of Coefficients

\begin{tabular}{|c|c|c|c|c|c|c|}
\hline \multicolumn{7}{|c|}{ Coefficients } \\
\hline \multirow{2}{*}{\multicolumn{2}{|c|}{ Model }} & \multicolumn{2}{|c|}{$\begin{array}{l}\text { Unstandardized } \\
\text { Coefficients }\end{array}$} & \multirow{2}{*}{$\begin{array}{c}\text { Standardized } \\
\text { Coefficients } \\
\text { Beta } \\
\end{array}$} & & \multirow[t]{2}{*}{ Sig. } \\
\hline & & B & Std. Error & & & \\
\hline \multirow[b]{2}{*}{1} & (Constant) & 62755.048 & 6109.730 & & 10.271 & .000 \\
\hline & $\begin{array}{l}\text { Working capital } \\
\text { conversion cycle }\end{array}$ & -816.198 & 142.128 & -.686 & -5.743 & .000 \\
\hline
\end{tabular}

Profitability $=62755.048-816.298$ Working capital conversion cycle

\subsection{Summary and Interpretation of Findings}

From the findings, the minimum annual debtor's collection period was 6.4 , while the maximum was 48.6.The mean of the annual debt collection period was spread within a standard deviation of 12.9.This implies that there was a wide spread of the reported annual average debtor's collection period from the mean collection period. The minimum annual debtor's conversion period was 6.4, while the maximum was 83.8. The mean of the annual debt conversion period was spread within a standard deviation of 17.8.This implies that there was a wide spread of the reported annual average debtor's conversion period from the mean collection period. The minimum reported deferral period was 16.8 while the maximum was 114.8 . The payable deferral period was spread within a standard deviation of 22.4 and this implies that there was a wide spread of reported deferral period from the mean deferral period.

There was a consistent rise in profit before tax across the five years of study. The linear plot yielded an $r$ square of 0.793 implying that $79.3 \%$ of changes in profitability can be explained by time and this further revealed a consistent trend. There was also a consistent decline in the annual debtor's collection period across the five years of study. The linear plot yielded an $r$ square of 0.973 implying that $97.3 \%$ of changes in debtor's collection period can be explained by time and this further revealed a consistent trend. There was a consistent decline in debtor's 
inventory conversion period across the five years of study. The linear plot yielded an $r$ square of 0.772 implying that $77.2 \%$ of changes in debtor's inventory conversion period can be explained by time and this further revealed a consistent trend. There was a consistent rise in payable deferral period across the five years of study. The linear plot yielded an $r$ square of 0.849 implying that $84.9 \%$ of changes in payable deferral period can be explained by time and this further revealed a consistent trend.

Building, construction and mining sector had the highest average profit before tax $(162,561$ Ghanaian cedi) while timber, wood and furniture sector had the lowest average profit before tax of 4, 324 Ghanaian cedi. Motor vehicles and accessories had the highest average debt collection period (48) while building, construction and mining sector had the lowest average debt collection period (19). Motor vehicles and accessories had the highest average inventory conversion period (68) while building, construction and mining sector had the lowest average inventory conversion period (10). Building, construction and mining sector had the highest average payment deferral period (85) while the motor vehicles and accessories had the lowest average payment deferral period (25).

The correlation between average profit before tax and the mean debtor's collection period was strong and negative $(-0.493)$ but statistically significant $(0.001)$. The correlation between average profit before tax and the mean inventory conversion period was weak and negative (-0.404) but was statistically significant $(0.011)$.The correlation between average profit before tax and mean payable deferral period was strong and positive (0.523) and was statistically significant (0.001).

The results indicate that the variables; mean payable deferral period, mean debtors collection period and mean inventory conversion period were satisfactorily explaining the mean profit before tax. This conclusion is supported by the R square of 0.575 . This further means that the independent variables can explain $57.5 \%$ of the independent variable (profit before tax). The overall model was statistically significant. This was supported by a probability $(\mathrm{p})$ value of 0.000 . The reported $\mathrm{p}$ value was less than the conventional probability of 0.05 significance levels thus its significance in the study. These results indicate that the independent variables are good predictors of profit before tax.

Regression of coefficients results in the first model show that there is a negative relationship between profit before tax and mean debtor's collection period and mean inventory conversion period whose beta coefficients are -1817.81 and -103.762 respectively. However both the mean debtor's collection period and mean inventory conversion period were statistically significant variables in the study with a significance level of 0.010 and 0.000 respectively which are lower than the probability conventional of 0.05 . This means that an increase in one unit of either mean debtor's collection period or mean inventory conversion period leads to a subsequent decrease in -1817.81 and -103.762 units of the dependent variable (profit before tax). The mean payable deferral period had a positive relationship with a beta coefficient of 1097.073 and was statistically significant (0.000). This means an increase in one unit of payable deferral period leads to a subsequent increase in the profit before tax. These findings further indicate that all the independent variables were satisfactory in explaining the dependent variable (profit before tax).

Regression of coefficients of Model 2 shows that there is a negative relationship between profit before tax and working capital conversion cycle with a beta coefficient of -816.198 . However, the working capital conversion cycle was a statistically significant variable in the study with a 
significance level of 0.000 which is lower than the probability conventional of 0.05 . This means that an increase in one unit of working capital conversion cycle leads to a subsequent decrease of the dependent variable (profit before tax) by -816.198 units.

\subsection{SUMMARY OF FINDINGS, CONCLUSIONS AND RECOMMENDATIONS}

\subsection{Summary}

From the study, the first objective was to assess the effect of inventory conversion period on profitability of large manufacturing firms in Ghana. The mean debtor collection period was statistically significant in explaining the dependent variable (profitability). However, the mean debtor collection period was negatively correlated to the profitability implying that an increase in one unit of the debt collection period led to a decrease in the profitability of the manufacturing firms in Ghana. Results show that there is a negative relationship between profit before tax and mean debtor's collection period whose beta coefficients is -1817.81 .

These findings agree with Deloof (2003) who using correlation and regression tests found a significant negative relationship between gross operating income and the number of days accounts receivable, inventories and accounts payable of Belgian firms. Mathuva,(2009) also found a negative relationship between number of day's accounts payable and profitability is consistent with the view that less profitable firms wait longer to pay their bills.

The second objective sought to assess the effect of receivables conversion period on profitability of large manufacturing firms in Ghana. The annual debtor's conversion period was statistically significant in explaining the dependent variable. It however had negative correlation with profitability implying that an increase in one unit of the debtor's conversion period led to a decrease in the same proportion of profitability of the manufacturing firms in Ghana. Results show that there is a negative relationship between profit before tax and mean inventory conversion period whose beta coefficients is -103.762 .

The results also agree with Gill et al (2010) who using a sample of 88 firms listed on New York Stock Exchange investigate the relationship between the level of a firms' working capital and its profitability. They find a significant relationship between the cash conversion cycle and firms' profitability. They postulate that a firm profitability is increased the shorter the accounts receivable collection period.

The third objective was to establish effect of payable deferral period on profitability of large manufacturing firms in Ghana. The payable deferral period was statistically significant when explaining the dependent variable (profitability).It also had a positive correlation with profitability implying that an increase in one unit of the debt collection period led to a decrease in the profitability of the manufacturing firms in Ghana.The mean payable deferral period had a positive relationship with profitability with a beta coefficient of 1097.073.

The results of the study are consistent with Raheman and Nasr (2006) who also found that there is a significant negative relationship between liquidity and profitability. They also found that there is a positive relationship between size of the firm and its profitability. There is also a significant negative relationship between debt used by the firm and profitability. 
The fourth objective was to establish the overall effect of the working capital cycle conversion period on profitability of large manufacturing firms in Ghana. From the findings it was found that the working capital cycle conversion period was statistically significant in explaining profitability of large manufacturing firms in Ghana.The findings show that there is a negative relationship between profit before tax and working capital conversion cycle with a beta coefficient of -816.198 .

The results are consistent with Zariyawati et al. (2009) who examined the relationship between working capital management and corporate profitability. Cash Conversion Cycle was used as a measured for working capital management and the study was based on panel data for 1,628 company-years for the period 1996-2006 from six different economic sectors listed in Bursa Malaysia. The coefficient results of Pooled OLS regression analysis provided a strong negative significant relationship between Cash Conversion Cycle and corporate profitability.

\subsection{Conclusions}

From the study it can be concluded that the profit before tax for the manufacturing has improved over the last five years. The average debt collection period has decreased for the five years under study which implies that the manufacturing firms have put in place effective debt management practices such as credit appraisals and stringent debt collection. The findings revealed that there is a significant negative relationship between average debt collection period and profit before tax and this implies that the lower the number of days taken to collect a debt the higher the probability as bad debts is reduced.

From the study it can be concluded that the average debt conversion period has decreased for the five years under study which implies that the manufacturing firms have put in place effective debt conversion practices such as credit appraisals and stringent debt collection. The findings revealed that there is a significant negative relationship between average debt conversion period and profit before tax and this implies that the lower the number of days taken to collect a debt the higher the probability as bad debts is reduced.

From the study it can be concluded that the average debt payable deferral has increased for the five years under study which implies that the manufacturing firms have put in place effective measures to counter debt deferral. The findings revealed that there is a significant positive relationship between average debt collection period and profit before tax and this implies that the higher the number of days took to collect a debt the higher the probability as bad debts is reduced.

From the study it can be concluded that the working capital conversion cycle has decreased for the five years under study. The findings revealed that there is a significant negative relationship between working capital conversion cycle and profit before tax and this implies that the lower the number of days taken to convert capital the higher the probability.

\subsection{Policy Recommendations}

It was recommended that speeding up payments to suppliers might increase profitability because firms often receive a substantial discount for prompt payment. 
It was also recommended that the government should intervene by way of a legislation that would impose penalty interest for delayed payment of commercial debts. Such a provision would create a level playing field by binding all firms to pay promptly and ease the cash flow problems of small firms, who will be compensated for any overdue payments.

It was recommended that the owners of firms be made more aware and trained on the best credit management practice. That way, they could reduce the amount of overdue debt and alleviate the problem.

\subsection{Suggested Areas of Further Research}

Future studies should consider addressing the effect of debt financing on the performance of manufacturing firms.

The study suggests that further areas of study should be on investigating the effect of mass production in manufacturing firms on profitability.

Future studies should examine how governance of manufacturing firms affects the profitability of such firm. 


\section{References}

Aryeetey, E. (1994). Supply and Demand for Finance of Small Enterprises in Ghana, World Bank Discussion Paper, Africa Technical Department Series No. 251, Washington , D.C., U.S.A.

Cosh, A.D. \& Hughes, A. (1994). Finance and the small firm (p.p 18-63). London: Routledge,

Dawson, J. (1988). Small-Scale Industry Development in Ghana: A Case Study from Kumasi, ESCOR (Erimeo), London; Overseas Development Administration.

Deloof, M. (2003). Does Working Capital Management Affect Profitability of Belgian Firms?. Journal of Business Finance \& Accounting, 30 (3\& 4), p. 585.

Dodge, H., Fullerton, S. \& Robbins, J. (1994). State of organisational life cycle and competition as mediators of problem perception for small businesses. International Small Business Journal, 15, 121-134

Falope, O. I. and Ajilore, O. T. (2009). Working capital management and corporate profitability: evidence from panel data analysis of selected quoted companies in Nigeria. Research Journal of Business Management, 3, 73-84.

Fischer-Q.G. (1990). Small Enterprises for the Needs of the People? Ghana's Small-Industrial Take-Off, in African Development Perspectives Yearbook, Volume 1: Human Dimension of Adjustment, Berlin Schelzky Jeep.

Garcia,J,P and Solano, M.P.(2007). Effects of Working Capital Management on SME profitability, Journal of Managerial Finance. 3(2),164-177.

Gill. Amarjit, Biger. Nahum and Mathur. Neil(2010)," The Relationship Between Working Capital Management And Profitability: Evidence From The United States", Business and Economics Journal, Volume 2010, pp:1-9.

Kessous, J. and Lessard, G. (1993). Industrial Sector in Mali: Responses to Adjustment, in: Helmsing and Kolstee. 
Lazaridis I, Tryfonidis D. (2006.), "Relationship between working capital management and profitability of listed companies in the Athens stock exchange". Journal of Financial Management and Analysis, 19: 26-25.

Lindsay, J. (2008). Trade credit strategies for turbulent times. Journal of Institute of Credit Management, 16,17.

Mathuva D, (2009). The influence of working capital management components on corporate profitability: a survey on Kenyan listed firms. Research Journal of Business Management, 3, 1- 11.

Maxime,A,.(2008). The impact of working capital management on cash holdings :A Quantitative study of swedish manufacturing smes.

Mumbengegwi, C. (1993). Structural Adjustment and Small-Scale Enterprise Development in Zimbabwe, in: Helonsing and Kolstee.

Nobanee and AlHajjar (2009b), "A note on working capital management and corporate Profitability of Japanese firms" home page, in http://papers.ssrn.com/sol3/papers.cfm?abstract_id=1433243 accessed on June 16, 2011

Nwanko, S. \& Richardson, S. (1994). Understanding the Causes of Business Failures Crises: Generic Failure Types. Management Decisions, 32(4), 9-22.

Pass, C. and Pike, R. (1984) 'An overview of working capital management and corporate financing', Managerial Finance, Vol. 10, No. 3/4, pp. 1-11.

Peel, M. J. \& Wilson, N. (1996). Working capital and financial management practices in the small firm sector. International Small Business Journal, 14, 52-68.

Peel, M. J., Wilson, N. \& Howorth, C. (2000). Late Payment and Credit Management in the small Firm Sector: Some Empirical Evidence. International Small Business Journal, 8, 17.

Peel, M. J., Wilson, N. and Howorth, C. (2000). Late Payment and Credit Management in the Small Firm Sector: Some Empirical Evidence. International Small Business Journal, 18, 17-37. 
Raheman A, Nasr M. (2007), "Working capital management and profitability - case of Pakistani firms". International Review of Business Research Papers, 3: 279-300.

Raheman, Abdel and Nasr,N. (2007). Working Capital Management and Profitability Case of Pakistani Firms, International Review of Business Research Papers.3(1), 279 - 300.

Ramin C. Maysami Understanding and Controlling Cash Flow Financial Management Series $F M-4$

Samiloglu F., Demirgunes K. (2008), "The effect of working capital management on firm profitability: Evidence from Turkey". The International Journal of Applied Economics and Finance 2: 44-50

Scott Besley, Eugene. \& Brigham(2006) working capital management concept

Sharma, A. K. and Kumar, S. (2011). Effect of Working Capital Management on Firm Profitability. Global Business Review, 12(1), 159-173.

Shin HH, Soenen L. (1998), "Efficiency of working capital management and corporate Profitability”. Financial Practice and Education, Vol. 8: 37-45.

Sowa, N.K., Baah-Nuakoh, A., Tutu, K.A. and Osei, B. (1992). Small Enterprises and djustment the Impact of Ghana's Economic Recovery Programme, London/Accra: Overseas Development Institute/University of Ghana.

Steel, W.F. (1991). Small Enterprises under Adjustment in Ghana Technical Paper No. 138.World Bank, Washington, D.C., U.S.A.

Stein, H. (1992). De-industrialisation, Adjustment, the World Bank and the International Monetary Fund (IMF) in Africa, World Development 20 (1), 83- 95.

Valk, Peter de (1994). A Review of Literature on Sub-Saharan African Industry in: Rolph Van Der Hoeven and Fred Van Der Kraalj (ed) Structural Adjustment and Beyond in SubSaharan Africa, Heinemann, Portsmouth (N.H.). 